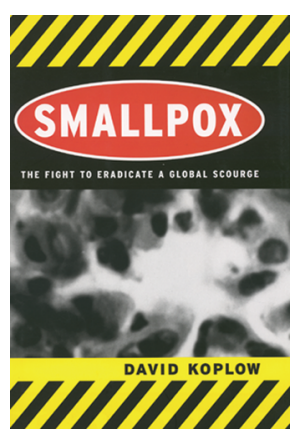

\section{Smallpox: the fight to eradicate a global scourge}

\author{
By David A. Koplow
}

University of California Press. Berkeley, California, USA. 2003. 274 pp. \$24.95. ISBN: 0-520-23732-3 (hardcover).

\section{Reviewed by Ariella M. Rosengard}

E-mail: arosenga@mail.med.upenn.edu

Since the eradication of smallpox two decades ago, the debate over whether to destroy the remaining vestiges of the variola virus has continued. David Koplow, in his scholarly treatise Smallpox: the fight to eradicate a global scourge, presents a comprehensive analysis of the historical, scientific, social, ethical, and political arguments that have shaped the debate. A Professor of Law at Georgetown University and former Deputy General Counsel for International Affairs at the US Department of Defense, Koplow methodically explores the arguments on both sides of the debate, ultimately concluding in favor of preserving the remaining known vials of the virus. His book should be read by all scientists interested in microbiology and by those who wish to opine on the subject of smallpox. It should also not be ignored by government policy makers who will decide the fate of the known remaining stocks of smallpox in the United States and Russia.

Koplow initially dissects the medical, scientific, and military issues that underlie the wide variety of policies and attitudes concerning smallpox. He describes the magnitude of the "variola problem" by recounting the history of the rise and fall of this disease and the unprecedented achievement of the World Health Organization in eradicating it. For the nonscientist, Koplow provides an overview of virology and of the theoretical possibility that molecular manipulations of viral DNA could result in an even more lethal form of smallpox than previously seen. Next, Koplow presents the historical prece- dence for using smallpox for military advantage and shows how variola could be used as a biological weapon today. As Koplow describes, "biological weapons are much more dangerous than other weapons of mass destruction such as nuclear arms or chemical agents." Native Americans were decimated by smallpox introduced by European colonizers, and this provided Europeans with some military advantage. Because routine smallpox vaccination programs were halted over 25 years ago, Koplow believes that the population of the world today, like Native Americans of the 17th century, would be exceptionally vulnerable to an outbreak of smallpox.

The book then presents arguments that are not often included in the debate regarding the destruction of variola. Koplow details environmental laws that are designed to protect wildlife species and biodiversity. $\mathrm{He}$ conflict with the decision to deliberately destroy a species, in this case, the variola virus.

Koplow cites the multiple deadlines (in 1993, 1995, and 1999) that the World Health Organization has set for destroying the remaining virus stocks. All of these deadlines have come and gone. At the time that he submitted his book for publication, December 2002 had been selected as the next date for the final eradication. Again, however, the date passed without action. The likely cause was the terrorist attacks on September 11, 2001, which spurred increased bioterrorism-related research in the United States. The Bush adminmakes the case that these laws may istration determined that the virus should not be destroyed until scientists accomplished several research objectives; these include developing novel detection techniques as well as two unique therapies for smallpox and a safer smallpox vaccine. As Koplow explains, despite the World Health Organization's recommendation that the variola samples be destroyed, the agency lacks legal authority over the decisions of the governments of the United States and Russia.

Among basic scientists like myself, the least discussed aspect of variola destruction is the ethical one: the morality of knowingly and willfully destroying a species. Admitting that the answer to this ethical issue is a difficult one, Koplow questions the wisdom of destroying a virus knowing that a precedent will be set for the next time man considers the deliberate extinction of another species.

After dissecting the intertwined issues, Koplow reveals his legal background by constructing two opposing theses - one in support of variola destruction and the other against. In each case, he presents five superb arguments along with excellent rebuttals, drawing upon the information described earlier in the book.

In the final chapter Koplow concludes that by destroying the virus, albeit "a confirmed enemy of our species," we close a door that we can never pass through again. He states that only hubris would lead man to conclude that, with the DNA sequences of variola virus in hand, we no longer need the entire virus for future studies. Indeed, recent papers presented since Koplow's book was submitted for publication suggest that specific characteristics of variola proteins could not have been predicted by DNA analysis alone. Future scientific advances may require the entire virus for studies involving tests that we cannot yet fathom. Koplow argues that we should hold on to variola "just in case." Whether or not readers agree with Koplow, they will enjoy his brilliant and witty writing and will be enriched by his outstanding effort. 